\title{
Effect of veneering material on the deformation suffered by implant-supported fixed prosthesis framework
}

\author{
Antônio Francisco GRANDO' ${ }^{1}$, Carlos Eduardo Edwards REZENDE², Edson Antônio Capello SOUSA ${ }^{3}$, José Henrique \\ RUBO $^{2}$
}

\author{
1- Department of Dentistry, University of Paraná, Cascavel, PR, Brazil. \\ 2- Department of Prosthodontics, Bauru School of Dentistry, University of São Paulo, Bauru, SP, Brazil. \\ 3- Department of Mechanical Engineering, Bauru School of Engineering, Univ. Estadual Paulista - UNESP, Bauru, SP, Brazil.
}

Corresponding address: José H. Rubo - Departamento de Prótese - Faculdade de Odontologia de Bauru - Universidade de São Paulo - Alameda Dr. Octávio Pinheiro Brisola, 9-75 - Vila Universitária - Bauru - SP - 7012-901 - Brazil - Phone: 55-14-3235-8231 - e-mail: jrubo@fob.usp.br

Submitted: September 8, 2013 - Modification: January 8, 2014 - Accepted: January 26, 2014

\section{ABSTRACT}

\begin{abstract}
Knowing how stresses are dissipated on the fixed implant-supported complex allows adequate treatment planning and better choice of the materials used for prosthesis fabrication. Objectives: The aim of this study was to evaluate the deformation suffered by cantilevered implant-supported fixed prostheses frameworks cast in silver-palladium alloy and coated with two occlusal veneering materials: acrylic resin or porcelain. Material and Methods: Two strain gauges were bonded to the inferior surface of the silver-palladium framework and two other were bonded to the occlusal surface of the prosthesis framework covered with ceramic and acrylic resin on each of its two halves. The framework was fixed to a metallic master model and a $35.2 \mathrm{~N}$ compression force was applied to the cantilever at 10, 15 and $20 \mathrm{~mm}$ from the most distal implant. The measurements of deformation by compression and tension were obtained. The statistical 2-way ANOVA test was used for individual analysis of the experiment variables and the Tukey test was used for the interrelation between all the variables (material and distance of force application). Results: The results showed that both variables had influence on the studied factors (deformation by compression and tension). Conclusion: The ceramic coating provided greater rigidity to the assembly and therefore less distortion compared with the uncoated framework and with the resin-coated framework. The cantilever arm length also influenced the prosthesis rigidity, causing higher deformation the farther the load was applied from the last implant.
\end{abstract}

Keywords: Dental implants. Dental prosthesis design. Dental veneers. Implant-supported dental prosthesis.

\section{INTRODUCTION}

The evaluation of the effectiveness of osseointegrated implants in the rehabilitation of edentulous patients showed the evolution of this type of treatment based on significant rehabilitative success rates ${ }^{27}$.

The concern in obtaining optimum association between veneering and framework materials from the mechanical and biological aspects to promote correct distribution of stress during function and, consequently, improve reliability of implant- supported prostheses has led several authors to study the effects of combining different types of metal alloys and coating materials for implantsupported prostheses ${ }^{4-7,11,14,24}$. Focus was directed to cantilevered implant-supported fixed prostheses because of their complex biomechanics $7,8,11,24$.

The cantilevered implant-supported fixed prosthesis generates mechanical stresses on the framework and the bone around the implants ${ }^{15,16}$. Such stresses can lead to bone loss ${ }^{1}$, as well as to other mechanical complications such as the loosening and fracture of the prosthesis screws, 
fracture of the veneering material, implant fracture, loss of osseointegration, fracture of the framework and fracture or loosening of the abutment ${ }^{14,21,28}$. The stress is directly related to variables such as the amount of load, incidence of force ${ }^{20}$, size and distribution of implants ${ }^{9}$ and extension of the cantilever $\operatorname{arm}^{11,17}$, which led to search for materials that promote biomechanical balance.

Stiff frameworks associated with occlusal coating materials that allow the absorption and balanced distribution of stress ensure the longevity of prostheses and implants ${ }^{16}$. On the other hand, the stress generated in the framework may cause the detachment of the veneering material ${ }^{6}$.

Porcelain has been widely used in fixed implant prostheses. However, it is not considered a good stress absorber, since the forces applied to the occlusal surface of the prosthesis are transmitted directly to the framework, implant components and bone tissue. Seeking greater shock absorption of impact forces on the prosthesis, the use of acrylic resin as the ideal coverage material has been suggested ${ }^{7,8}$. On the other hand, acrylic resins have presented higher wear when functioning as antagonist of enamel or ceramic material. For this reason, some authors do not recommend the use of acrylic resin as a veneering material ${ }^{10,23}$.

Due to the diversity of materials available, and after a careful evaluation of the relevant scientific literature, this study aimed at evaluating the deformation suffered by cantilevered implantsupported fixed prostheses frameworks cast in silver-palladium alloy and coated with two occlusal veneering materials: acrylic resin or porcelain. Two null hypotheses were formulated: 1- the different veneering materials do not influence the framework deformation; and 2- the cantilever arm length does not influence the framework deformation.

\section{MATERIAL AND METHODS}

This study evaluated occlusal veneering materials used in implant-supported fixed prostheses: Acrylic resin (Palapress Vario ${ }^{\circledR}$, Heraeus Kulzer, Hanau, Germany) and a feldspathic ceramic (Noritake EX3, Noritake Co., Nagoya, Japan). These materials were applied on a metallic framework cast in silver-palladium alloy (Pors-on ${ }^{\mathrm{TM}} 4$, Degussa, São Paulo, SP, Brazil), simulating a cantilevered implantsupported fixed prosthesis. This prosthesis was secured on five intermediate conventional $4 \mathrm{~mm}$ height abutments (Conexão Sistemas de Prótese Ltda., Arujá, SP, Brazil), which were positioned and screwed with $20 \mathrm{Ncm}$ torque, using an electronic torque controller (Nobel Biocare torque Controller ${ }^{\mathrm{rm}}$, Gothenburg, Sweden), onto five external hexagon implant replicas (Conexão Sistemas de Prótese Ltda., Arujá, SP, Brazil) with $3.75 \mathrm{~mm}$ in diameter, set in a circular stainless steel master model (Figure $1)$.

\section{Framework fabrication}

Prosthetic gold cylinders (Conexão Sistemas de Prótese Ltda, Arujá, SP, Brazil) were attached to the abutment replicas for construction of wax patterns with the following dimensions: $75 \mathrm{~mm}$ in length, 6 $\mathrm{mm}$ in width, and $4 \mathrm{~mm}$ in height. The cantilever arms measured $23.5 \mathrm{~mm}$ on both sides. They were then invested and cast in one piece.

After casting, an occlusal radiograph of the infrastructure was taken (Rx $100 \mathrm{Kv}$ GE General Electric) to verify possible defects arising from the casting process. The framework was positioned on the abutments on the master model and was manually tested in order to verify the presence of any jiggling movement.

\section{Veneer material application}

Mechanical retentions were created on half of the framework surface to allow the retention of acrylic resin, which was conducted from blasting with glass beads and small grain size particles of aluminum oxide. This procedure was not necessary for the other half to be covered with ceramic.

After this procedure, half of the framework was covered with a $2.5 \mathrm{~mm}$ layer of porcelain and the other half with a $10 \mathrm{~mm}$ of acrylic resin. In addition to the air abrasion performed on the framework to receive the acrylic resin, a cyanoacrylatebased adhesive was used, in order to optimize the retention of the resin.

\section{Strain gauge positioning}

The readings of the strain generated in the framework after load application was performed in three different groups: control group (C) framework without any covering material; acrylic resin group (AR) - framework covered with acrylic

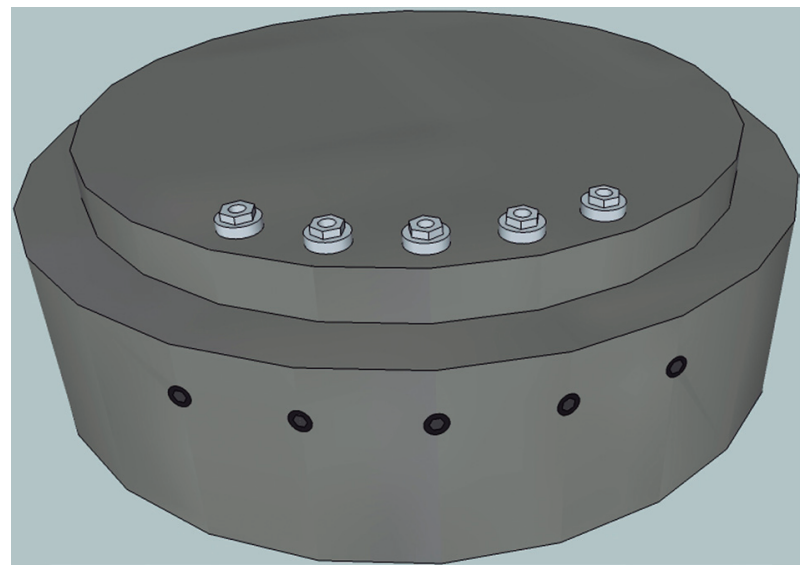

Figure 1- Circular steel-made master model with implant replicas. The perforations on the front of the master model were used to fix the replicas by lateral allen screws 
resin; and ceramic group (Ce) - framework covered with ceramic.

Prior to the application of the veneering materials, the metal framework received two strain gauges, one on the upper surface (to register tension forces) and another on the bottom of the framework (to register compression forces) under the application of a compressive load of $35.2 \mathrm{~N}$ on the occlusal surface of the prosthesis.

Two linear strain gauges (KFG - 02-120-C1-11, Strain Gages, Kyowa Electronic Instruments Co. Ltd., Tokyo, Japan) were fixed with cyanoacrylatebased adhesive (Strain Gages Cement CC - 33A, Kyowa Electronic Instruments Co. Ltd.) on the occlusal and underside aspects of each side of the prosthesis to register the data of strain by compression and by tension (Figure 2a).

\section{Reading compression deformation}

Before connection of the prosthesis, all strain gauge readings were set to zero. This procedure was performed before testing the prosthesis to avoid the stress caused by the abutment screw tightening from interfering with the results.

The master-cast was taken to a Universal Testing Machine (model K - 2000MP, Kratos Equipamentos Industriais Ltda., São Paulo, SP, Brazil) for load application (Figure $2 b$ ). A round steel point was fixed to the load cell and adjusted to predetermined reference points $(10,15$, and $20 \mathrm{~mm}$ ) on the cantilever arm (Figure 2c). Thus, the testing machine was set to compression at the crosshead speed of $0.5 \mathrm{~mm} / \mathrm{min}$ until it reached $32.5 \mathrm{~N}$. This load was established during a pilot test, which consisted of a compressive failure load application to a framework coated with ceramic and resin, that showed this load would be safe to avoid porcelain and resin fracture. The load application was performed by only one operator and was repeated ten times for each distance of cantilever arm so that a mean value of each point of load application could be obtained later in the process.
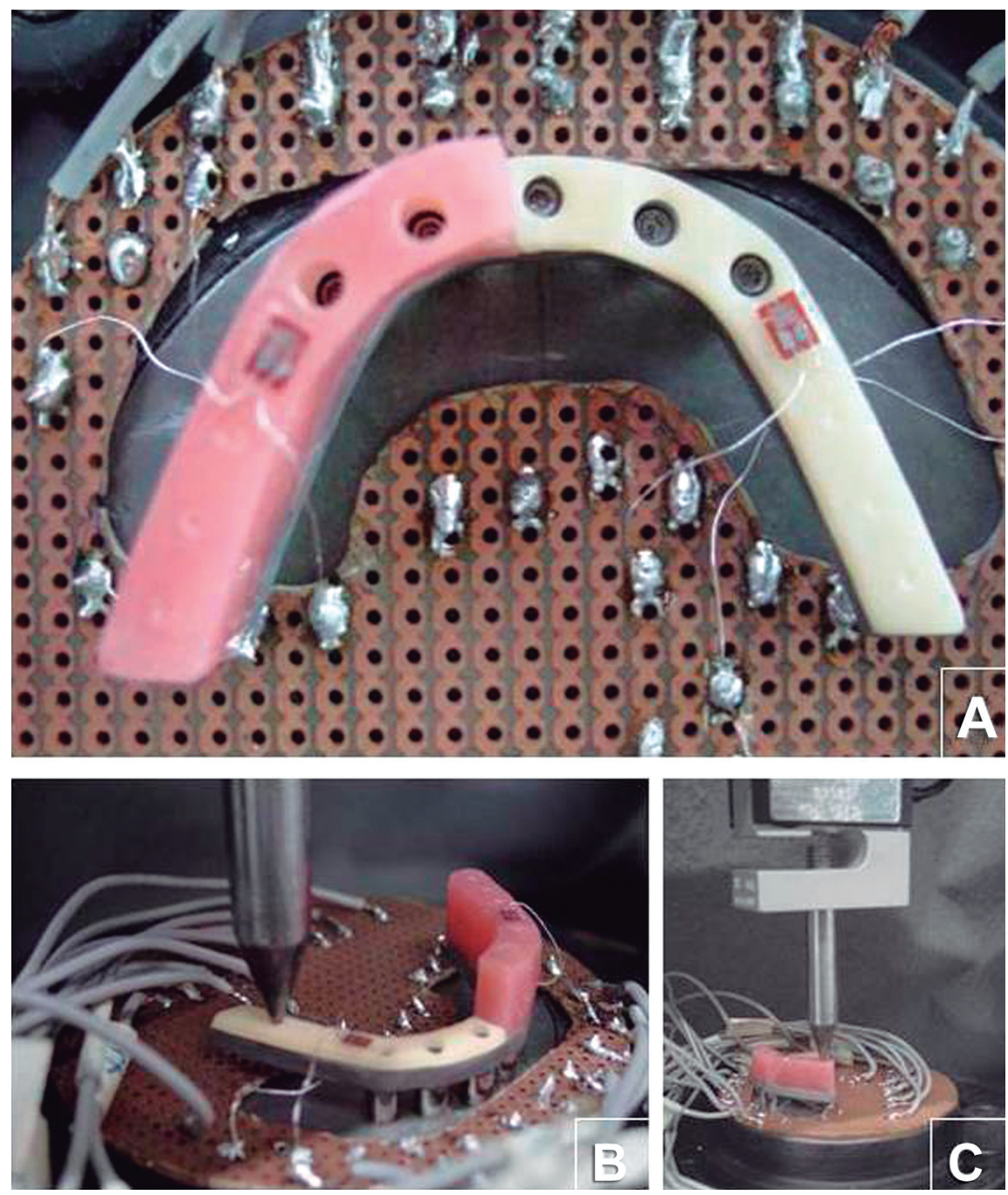

Figure 2- A) Framework covered with acrylic resin and ceramic; strain gauges were fixed to the occlusal and gingival aspects of the framework; B) Master-cast placed in the Universal Testing Machine for compressive load application; C) Load applied to a predetermined reference point on the cantilever arm 
A five minutes standard interval of waiting for each application was used. The same test was previously performed for the control group.

Strain gauges were connected to a data acquisition board (SC - 2042 - SG, National Instruments Corp., Austin, TX, USA) that sent the signal to a reading board (PCI - MIO - 16XE - 10, National Instruments Corp.) which was installed in a desktop computer. Inputs from the 4 strain gauges were analyzed with the aid of the LabVIEW FDS version 5.1 for Windows (National Instruments Corp.). Each strain gauge corresponded to a channel on the data acquisition board.

Approximately 500 readings were taken at each strain gauge, but only the last 100 were taken into account to calculate the mean to ensure that only maximum and stable levels of deformation were recorded, in $\mu \varepsilon$.

The data collected through the deformation tests were tabulated and analyzed by the theory of confidence intervals $(\alpha=0.05)$. After the statistical data tabulation, the two major and two minor mean values were excluded for each group. Among the remaining values, the one that had the higher standard deviation was also excluded. Thus, only the five remaining results were used for statistical analysis. The statistical 2-way ANOVA test was used for individual analysis of the experiment variables and the Tukey test was used for inter-relation between both veneering material and distance of force application. This procedure was performed using the STATISTICA 10 Software (Statsoft Inc, Tulsa, OK, USA).

Table 1- Mean values (MV) and standard deviation (SD) for compression deformation $(\mu \varepsilon)$ for the different groups at different points of the force application

\begin{tabular}{ccc}
\hline Material & Distance & $\begin{array}{c}\text { Compression } \\
\text { Mean } \pm \text { SD }\end{array}$ \\
\hline Resin & $10 \mathrm{~mm}$ & $83.51 \pm 9.94^{\mathrm{G}}$ \\
\hline Ceramic & $10 \mathrm{~mm}$ & $112.46 \pm 11.54^{\mathrm{B}}$ \\
\hline AgPd & $10 \mathrm{~mm}$ & $131.35 \pm 10.33^{\mathrm{B}}$ \\
\hline Resin & $15 \mathrm{~mm}$ & $294.88 \pm 10.74^{\mathrm{A}}$ \\
\hline Ceramic & $15 \mathrm{~mm}$ & $200.38 \pm 8.6^{\mathrm{F}}$ \\
\hline AgPd & $15 \mathrm{~mm}$ & $232.95 \pm 3.3^{\mathrm{E}}$ \\
\hline Resin & $20 \mathrm{~mm}$ & $490.59 \pm 16.94^{\mathrm{C}}$ \\
Ceramic & $20 \mathrm{~mm}$ & $301.44 \pm 8.85^{\mathrm{A}}$ \\
\hline AgPd & $20 \mathrm{~mm}$ & $329.62 \pm 5.46^{\mathrm{D}}$ \\
\hline
\end{tabular}

*Different letters represent statistically significant differences between the groups for the Tukey test $(p<0.05)$

Table 2- Mean values (MV) and standard deviation (SD) for tension deformation $(\mu \varepsilon)$ for the different groups at different points of the force application

\begin{tabular}{ccc}
\hline Material & Distance & $\begin{array}{c}\text { Tension } \\
\text { Mean } \pm \text { SD }\end{array}$ \\
\hline Resin & $10 \mathrm{~mm}$ & $82.64 \pm 14.01^{\mathrm{a}}$ \\
\hline Ceramic & $10 \mathrm{~mm}$ & $70.55 \pm 11.86^{\mathrm{a}}$ \\
\hline AgPd & $10 \mathrm{~mm}$ & $129.68 \pm 5.02^{\mathrm{b}, \mathrm{d}}$ \\
\hline Resin & $15 \mathrm{~mm}$ & $111.25 \pm 15^{\mathrm{b}, \mathrm{c}}$ \\
\hline Ceramic & $15 \mathrm{~mm}$ & $125.52 \pm 9.53^{\mathrm{b}}$ \\
\hline AgPd & $15 \mathrm{~mm}$ & $271.17 \pm 43.9^{\mathrm{e}}$ \\
\hline Resin & $20 \mathrm{~mm}$ & $93.27 \pm 15.53^{\mathrm{a}, \mathrm{c}}$ \\
\hline Ceramic & $20 \mathrm{~mm}$ & $155.59 \pm 8.52^{\mathrm{d}}$ \\
\hline AgPd & $20 \mathrm{~mm}$ & $308.14 \pm 1.32^{\mathrm{f}}$ \\
\hline
\end{tabular}

*Different letters represent statistically significant differences between the groups for the Tukey test $(p<0.05)$ 


\section{RESULTS}

Based on the statistical analysis, both variables (material and distance) had influence on the studied factors (deformation by compression and by tension).

Tables 1 and 2 show the mean values and standard deviation of the results obtained for deformation by compression and by tension for all the groups tested and different points of force application.

The comparison of mean values of compression and tension forces for different materials as a function of load application distance can be seen in Figures 3, 4 and 5, for $10 \mathrm{~mm}, 15 \mathrm{~mm}$ and $20 \mathrm{~mm}$, respectively. Such graphs show that the porcelain increased the resistance to deformation by compression in relation to the uncoated framework. The acrylic resin was more efficient at the $10 \mathrm{~mm}$ point. At the other application points, there was a relationship between deformation and distance of load application. The farther the load was applied, the greater the deformation observed on the specimen.

The comparison between the different distances of force application for all the conditions tested is demonstrated in Figures 6, 7 and 8, for metal, resin-veneered, and ceramic-veneered frameworks, respectively. These graphs show the effect of

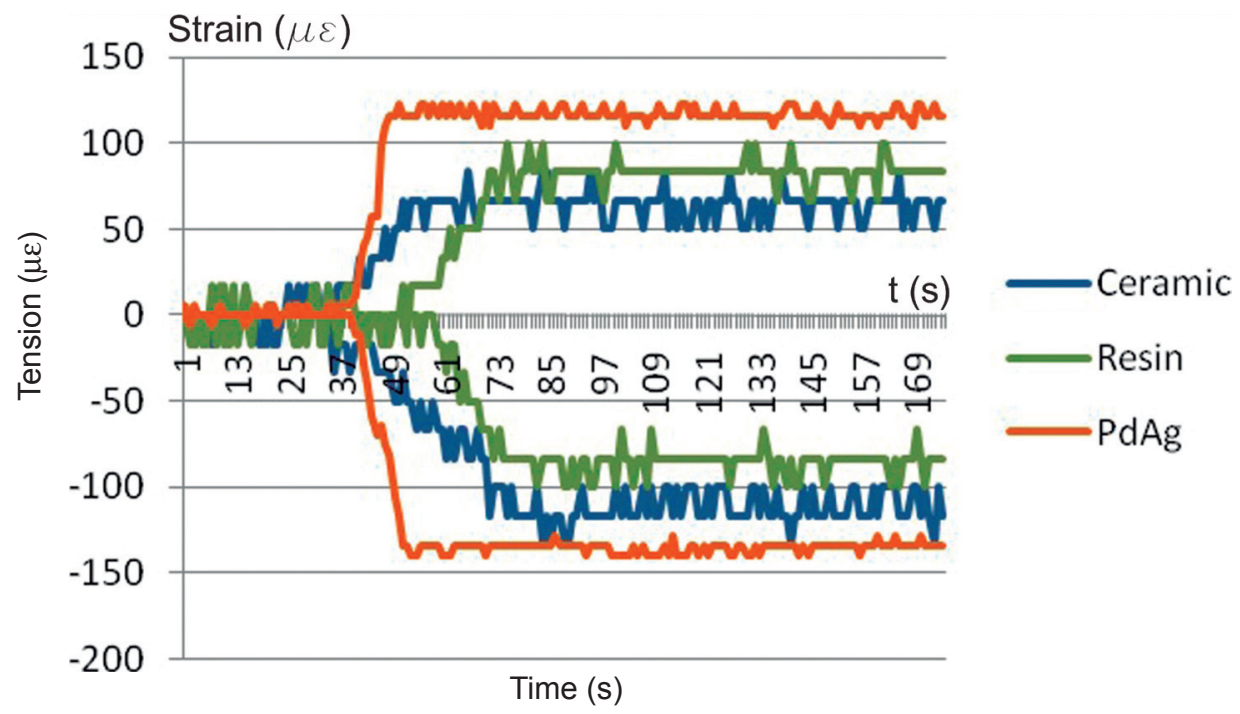

Figure 3- Measurements for tension (positive values) and compression (negative values) forces applied at $10 \mathrm{~mm}$ of the distal implant for the different conditions tested.

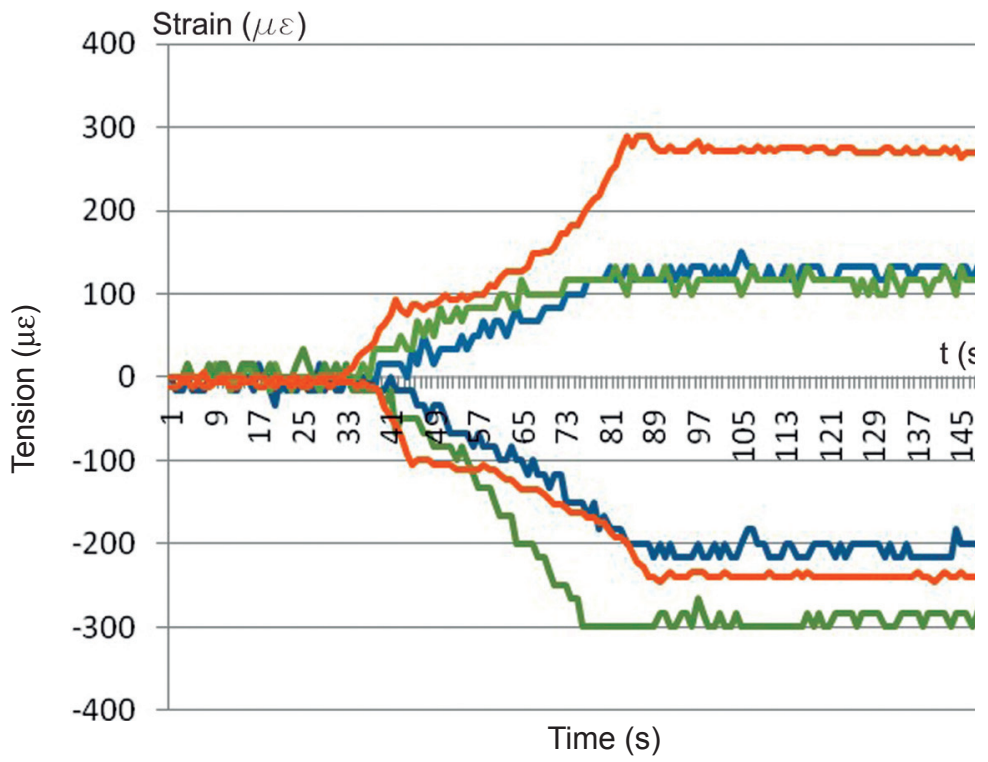

Figure 4- Measurements for tension (positive values) and compression (negative values) forces applied at $15 \mathrm{~mm}$ of the distal implant for the different tested materials. 


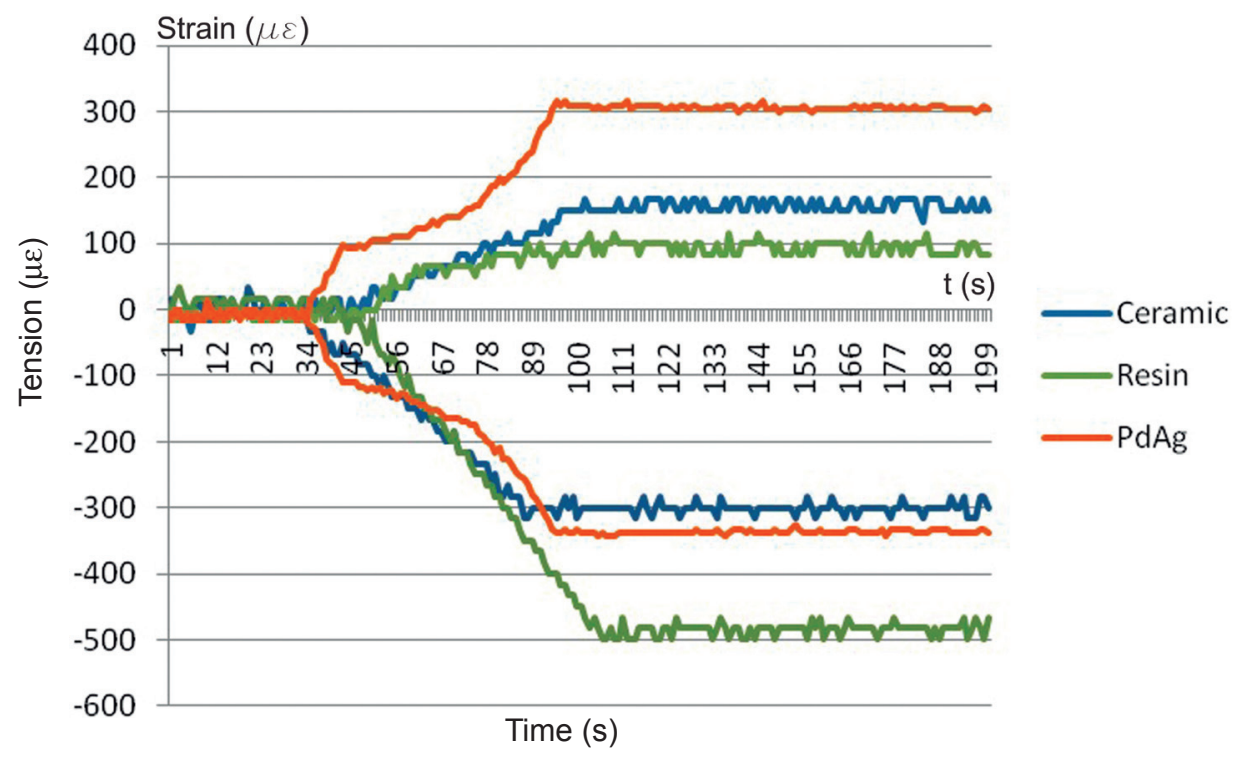

Figure 5- Measurements for tension (positive values) and compression (negative values) forces applied at $20 \mathrm{~mm}$ of the distal implant for the different tested materials.

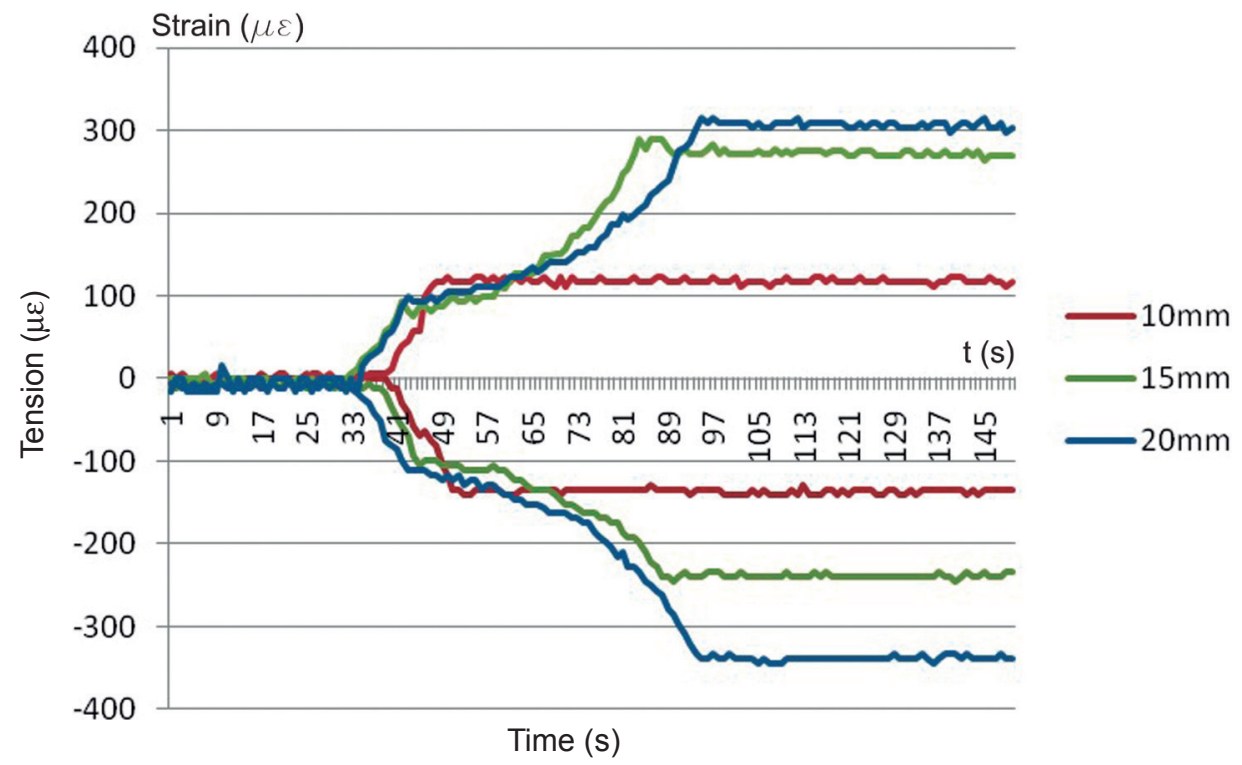

Figure 6- Measurements for tension (positive values) and compression (negative values) in different points of force application for Control group (C) - Palladium-Silver Framework.

the cantilever arm length on the framework and veneering material deformation.

\section{DISCUSSION}

No null hypothesis was confirmed. The two evaluated variables, veneering material and cantilever arm length, showed some influence on the deformation suffered by the implant-supported prosthesis framework. Based on the results, better performance was observed for the uncoated PdAg framework and the porcelain/PdAg groups, when compared with the acrylic resin/PdAg group for compressive load, except for the $10 \mathrm{~mm}$ cantilever extension.

The correct arrangement of the implants in the edentulous space to be rehabilitated can allow better distribution of forces applied to the system implantprosthesis-bone ${ }^{13}$. However, bone limitations have required the use of prostheses with cantilever extensions. These prostheses were the most successful in the mandibular arch due to the bone quantity and quality, which allows the placement of 15 to $20 \mathrm{~mm}$ cantilever extensions ${ }^{11,12,19,25,26}$.

Understanding the distribution of loads and generation of tension within an implant prosthesis system requires a study to qualitatively and quantitatively assess the levels of stress generated 


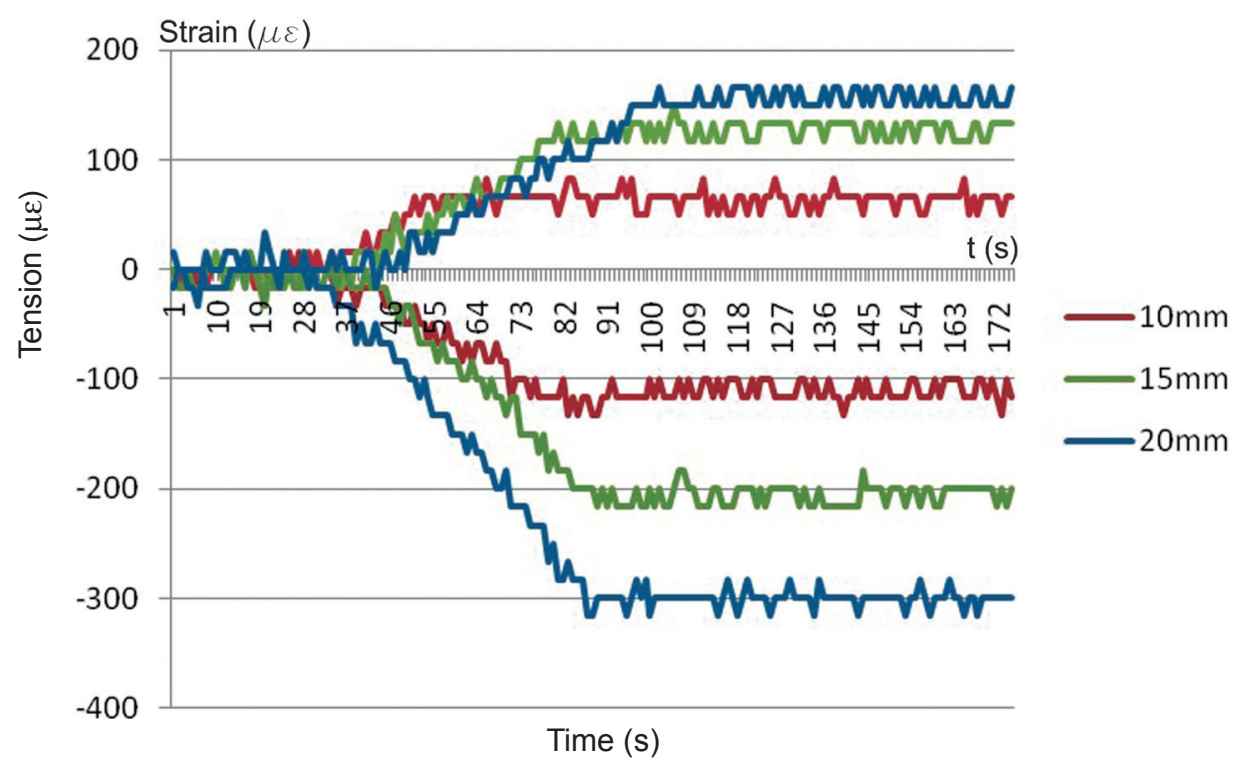

Figure 7- Measurements for tension (positive values) and compression (negative values) in different points of force application for Ceramic group (Ce).

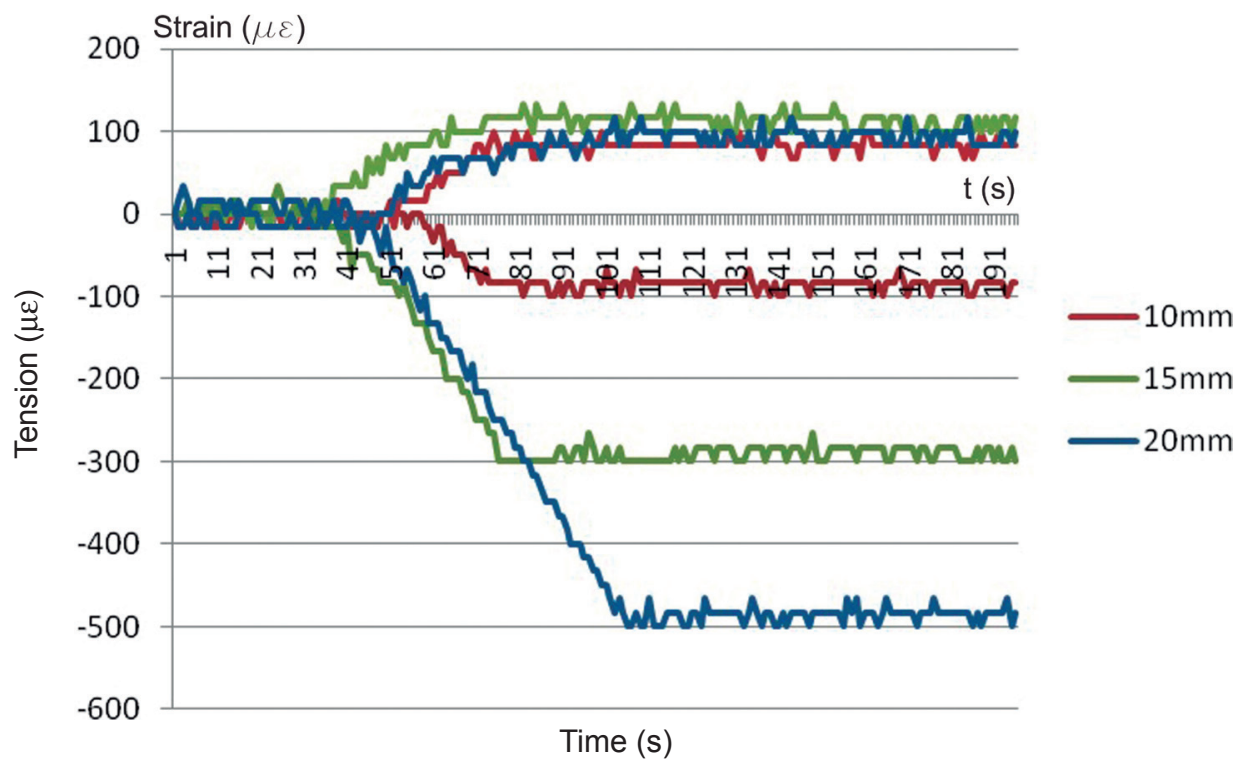

Figure 8- Measurements for tension (positive values) and compression (negative values) in different points of force application for Acrylic Resin group (AC).

during the masticatory function. The evaluation of the deformation of the materials used in implant prostheses using strain gauges has been used by several authors $3,4,7,9,11,19$, and is recommended by Akça, Cehreli and Iplikçioglu² (2002) as being reliable and accurate.

The study of the deformation of the metal framework alone is not sufficient to predict the load distribution on implant-supported prostheses, since the framework must be veneered with a material that replicates the shape and aesthetics of natural teeth. After application of the veneering material on the respective halves of the framework and submission to a compressive load of $35.2 \mathrm{~N}$, there are some peculiarities.

The load applied at the point closest to the terminal implant for the acrylic resin, porcelain and uncoated bars generated strain values lower than the load applied to the most distant points, explaining the influence of the length of the cantilever extension in the rates of deformation, as stated by White, Caputo and Anderkvist ${ }^{26}$ (1994). The greater the extent of the cantilever, the greater its deformation, as noted by Jacques, et al. ${ }^{11}$ (2009), and Rubo and Souza ${ }^{16}$ (2010), even when alloys with higher elastic moduli are used. These data confirm the validity of the method used in this experiment. 
Comparing the results obtained for the frameworks coated and uncoated with acrylic resin or porcelain, it can be observed that the results of this study agree with the statement made by Ciftçi and Canay ${ }^{6}$ (2001), in which an increase in the stiffness of the joint framework/veneering material occurred and consequently reduced the rate of deformation of the infrastructure.

The addition of acrylic resin revealed that there was a compression strain decrease at the $10 \mathrm{~mm}$ point, but at the other points there were significant increases in the rates of deformation. This fact is probably due to the physical characteristics of the acrylic resin, which has lower elastic modulus than the porcelain. Another factor that has probably influenced the results is that to better simulate a clinical condition, the resin layer thickness used was larger than the ceramic layer. This can be considered a limitation of this study. Acrylic resin could favor the dissipation forces within the resin body when the load was applied at the $10 \mathrm{~mm}$ distance and provided less deformation of the bar. This is in agreement with the observations of Davis, Rimrott and Zarb7 (1988), who stated that acrylic resin could absorb part of the load.

However, it was observed that the values for acrylic resin veneering followed a direct relationship with longer distances and greater deformation, thus showing an increase from $10 \mathrm{~mm}$ to $15 \mathrm{~mm}$ and from $15 \mathrm{~mm}$ to $20 \mathrm{~mm}$. This behavior can be a result of the bending of the framework due to the increase of the lever arm at the free end, i.e., the increase in the moment applied by the load, agreeing with the reports of Stegaroiu, et al. ${ }^{22}$ (1998) and Ciftci and Canay $^{6}$ (2001). On the other hand, the ceramic veneering might have improved the prosthesis rigidity, resulting in less deformation.

Regarding the tension load, there was load absorption for the acrylic resin-veneered framework due to the lower elastic modulus of this material. This is in accordance with the findings of Çiftci and Canay $^{5}(2000)$, who found less deformation around implants for acrylic resin veneering.

Nevertheless, Santiago Jr, et al. ${ }^{18}$ (2013), after a finite element model analysis, stated that the veneering material had no influence on stress distribution around implants. Regarding the clinical aspect, according to Teigen and Jokstad ${ }^{24}$ (2012), the two veneering materials have comparable performances and both combinations have no influence on the success of the implants. Therefore, the choice of a veneering material, as observed in the clinical results, is case-dependent, since each material provides particular advantages and disadvantages.

For the sake of simplicity and initial observations, the model used in this study did not try to reproduce all anatomic aspects of an actual implant-supported prosthesis. In future studies, anatomic restorations using acrylic resin teeth plus denture base and porcelain build-up on individual teeth must be used to best reproduce the clinical condition.

\section{CONCLUSIONS}

Considering the tension forces, the veneering of the framework improved its rigidity independently of the material used.

Considering the compression forces, the porcelain veneering provided greater rigidity to the assembly and therefore less distortion compared with the uncoated framework and with the resin veneering.

The cantilever length had decisive influence on the rates of deformation, regardless of the aesthetic veneering materials used.

\section{REFERENCES}

1- Aglietta M, Siciliano VI, Zwahlen M, Brägger U, Pjetursson BE, Lang NP, et al. A systematic review of the survival and complication rates of implant supported fixed dental prostheses with cantilever extensions after an observation period of at least 5 years. Clin Oral Impl Res. 2009;20:441-51.

2- Akça K, Cehreli MC, Iplikçioglu H. A comparison of threedimensional finite element stress analysis with in vitro strain gauge measurements on dental implants. Int J Prosthodont. 2002;15:115-21.

3- Castro GC, Araújo CA, Mesquita MF, Consani RL, Nóbilo MA. Stress distribution in Co-Cr implant frameworks after laser or TIG welding. Braz Dent J. 2013;24:147-51.

4- Cibirka RM, Razzoog ME, Lang BR, Stohler CS. Determining the force absorption quotient for restorative materials used in implant occlusal surfaces. J Prosthetic Dent. 1992;67:361-4.

5- Çiftçi Y, Canay S. The effect of veneering materials on stress distribution in implant-supported fixed prosthetic restorations. Int J Oral Maxillofac Implants. 2000;15:571-82.

6- Çiftçi $Y$, Canay S. Stress distribution on framework of the implant-supported fixed prosthesis using different veneering materials. Int J Prosthodont. 2001;14:406-11.

7- Davis DM, Rimrott R, Zarb GA. Studies on frameworks for osseointegrated prostheses: Part 2. The effect of adding acrylic resin or porcelain to form the occlusal superstructure. Int J Oral Maxillofac Implants. 1988;3:275-80.

8- Gracis SE, Nicholls JI, Chalupnik JD, Yuodelis RA. Shockabsorbing behavior of five restorative materials used on implants. Int J Prosthodont. 1991;4:282-91.

9- Hollweg H, Jacques LB, Moura MS, Bianco VC, Sousa EA, Rubo $\mathrm{JH}$. Deformation of implant abutments after framework connection using strain gauges. J Oral Implantol. 2012;38:125-32.

10- Jacobi R, Shillingburg HT Jr, Duncanson MG Jr. A comparison of the abrasiveness of six ceramic surfaces and gold. J Prosthet Dent. 1991;66:303-9.

11- Jaques LB, Moura MS, Suedam V, Souza EA, Rubo JH. Effect of cantilever length and framework alloy on the stress distribution of mandibular-cantilevered implant-supported prostheses. Clin Oral Implants Res. 2009;20:737-41.

12- Korioth TW, Johann AR. Influence of mandibular superstructure shape on implant stresses during simulated posterior biting. J Prosthet Dent. 1999;82:67-72.

13- Naconecy MM, Geremia T, Cervieri A, Teixeira ER, Shinkai RS. Effect of the number of abutments on biomechanics of Branemark prosthesis with straight and tilted distal implants. J Appl Oral Sci. 2010;18:178-85. 
14- Purcell BA, McGlumphy EA, Holloway JA, Beck FM. Prosthetic complications on mandibular metal-resin complete denta prostheses: a 5- to 9-years analysis. Int J Oral Maxillofac Implants. 2008;23:847-57.

15- Rangert $B$, Jemt $T$, Jörneus $L$. Forces and moments on Branemark implants. Int J Oral Maxillofac Implants. 1989;4:241-7. 16- Rubo JH, Capello Souza EA. Finite-element analysis of stress on dental implant prosthesis. Clin Implant Dent Relat Res. 2010;12:105-13.

17- Salvi GE, Brägger U. Mechanical and technical risks in implant therapy. Int J Oral Maxillofac Implants. 2009;24:69-85.

18- Santiago Junior JF, Pellizzer EP, Verri FR, Carvalho PS. Stress analysis in bone tissue around single implants with different diameters and veneering materials: a 3-D finite element study. Mater Sci Eng C Mater Biol Appl. 2013;33:4700-14.

19- Sertgöz A, Güvener S. Finite element analysis of the effect of cantilever and implant length on stress distribution in an implantsupported fixed prosthesis. J Prosth Dent. 1996;76:165-9.

20- Sousa TC, Lelis V, Santos VM, Nishioka GN, Vasconcellos LG, Nishioka RS. Strain Gauge analysis of non-axial loads in three-element implant-supported prostheses. Braz Dent Sci. 2013; 16:24-30

21- Stafford GL. Survival rates of short-span implant-supported cantilever fixed dental prostheses. Evid Based Dent. 2010;11:501.
22- Stegaroiu R, Kusakari H, Nishiyama S, Miyakawa O. Influence of prosthesis material on stress distribution in bone and implant: a 3-dimensional finite element analysis. Int J Oral Maxillofac Implants. 1998;13:781-90.

23- Tanaka Y, Sugimoto T, Tanaka S, Hiranuma K. Development of a two-piece artificial resin tooth specially designed for a metal occlusal surface. Int J Prosthodont. 1990;3:292-8.

24- Teigen K, Jokstad A. Dental implant suprastructures using cobalt-chromium alloy compared with gold alloy framework veneered with ceramic or acrylic resin: a retrospective cohort study up to 18 years. Clin Oral Implants Res. 2012;23:853-60. 25- Van Zyl PP, Grundling NL, Jooste $\mathrm{CH}$, Terblanche $\mathrm{E}$. Three-dimensional finite element model of a human mandible incorporating six osseointegrated implants for stress analysis of mandibular cantilever prostheses. Int J Oral Maxillofac Implants. 1995; 10:51-7.

26- White SN, Caputo AA, Anderkvist T. Effect of cantilever length on stress transfer by implant-supported prostheses. J Prosthet Dent. 1994;71:493-9.

27- Zarb GA, Schmitt A. The longitudinal clinical effectiveness of osseointegrated dental implants: the Toronto study. Part II: The prosthetic results. J Prosthet Dent. 1990;64:53-61.

28- Zarb GA, Schmitt A. The longitudinal clinical effectiveness of osseointegrated dental implants: the Toronto study. Part III: Problems and complications encountered. J Prosth Dent. 1990;64:185-94. 